\title{
The Implementation of Field Trips as Edu-Tourism to Improve Students' Speaking Ability at University Level
}

\author{
Dina Irmayanti Harahap, Firdayanti Firdaus ${ }^{1}$ \\ ${ }^{1}$ University of Potensi Utama, Medan, North Sumatera
}

\begin{tabular}{|c|c|}
\hline ARTICLE INFO & ABSTRACT \\
\hline Article history: & \multirow{13}{*}{$\begin{array}{l}\text { Field trip programs as edu-tourism in university level were viewed as } \\
\text { the great equalizer in terms of delivering students to cultural heritage } \\
\text { awareness. So, they had seen these experiential learning as a central } \\
\text { of educational mission. Higher level education especially university } \\
\text { which implemented field trip programs as supporting activities in the } \\
\text { English for tourism lesson was gladly endured the expense and } \\
\text { disruption of providing field trips as the primary purpose to provide a } \\
\text { learning opportunity. The aim of this study was to evaluate the } \\
\text { implementation of educational field trips as edu-tourism at university } \\
\text { level. This is a qualitative study which is carried out by survey and } \\
\text { observation. The population of this study is the English Department } \\
\text { students of Potensi Utama University. There were } 150 \text { respondents in } \\
\text { this research which included of } 50 \text { teachers and } 100 \text { students were } \\
\text { randomly selected. The instrument of this study used questionnaires } \\
\text { and speaking test items. The questionnaire consisted of } 30 \text { items. The } \\
\text { collection of in this research were analysed by using simple } \\
\text { percentage method. The place for field trip activity was held in the } \\
\text { ecotourism of Bukit Lawang, which located at Bahorok sub-district, } \\
\text { Langkat Regency, North Sumatera, Indonesia. The result of this } \\
\text { study hoped that educational field trips are helpful to cope up with } \\
\text { advance learning to develop students interest especially speaking } \\
\text { ability. }\end{array}$} \\
\hline Received Jan 30, 2020 & \\
\hline Revised Mar 22, 2020 & \\
\hline Accepted May 18, 2020 & \\
\hline Keywords: & \\
\hline Implementation, & \\
\hline Field trip, & \\
\hline Edu-tourism, & \\
\hline Speaking Ability & \\
\hline Clonflict of Interest: & \\
\hline None & \\
\hline Funding: & \\
\hline None & \\
\hline
\end{tabular}

Corresponding Author: Dina Irmayanti Harahap, Universitas Potensi Utama, Medan, Indonesia. E-mail: Dinairmayanti4@gmail.com

Copyright $(\odot$ Association of Language Teachers in Southeast Asia. All rights reserved

\section{Introducation}

Studying English as a foreign language in an English speaking country has become a common practice in the last decades. This phenomenon can be examined from different perspectives. In terms of second language acquisition (SLA), the empirical evidence seems to suggest that the learners' communicative competence develops in every domain, but not always to a similar extent (Kinginger, 2013). There were extensive researches have been conducted in accordance with this area. The importance of foreign language (FL) skills in the tourism sector is necessary to revise foreign language skills including speaking. This conceptualization makes use of tourist services and engages not only in language learning tasks but also in tourist activities.

The main priority is to be able to hold a conversation and understand the needs of guests or customers (Leslie, Russell and Govan, 2004). It is obvious that engaging in effective communication plays an important role in tourist activities during field trips. There is no doubt that foreign language (FL) is the key skill supporting successful communication with international tourists. Therefore, applying an efficient model of FL teaching has got vital importance in tourism education. 
The purpose of education is to develop the knowledge, skill or character of students. Thus the education is the process of learning and knowing, which is not restricted to our school or textbooks. Education is very important for an individual life. Education is a major aspect of development of any modern society. The importance of education is evident at every stage of education whether at primary, secondary, high secondary and in higher education. Universities are the main institutions that provide higher education. MARY (2009) describes that higher education is said to produce that essential balance between theory and real practice in any given field.

Higher education is viewed as a source of great potential for the socio-economic and cultural development of the country. Higher education is rapidly changing our world and changes the things in new form. Our need of change in this level not only in academic side but student life also. As the students being the main clients of higher education. They are central part of learning process. Therefore, they not only required quality education but also effective and latest means of learning to have a better knowledge and have a command on what they are studding presently so they will able to apply that knowledge in their future lives also. For this purpose, different sort of activities like seminars, discussions, presentations, workshops, local conferences, lectures and educational field trips are essentials to conduct at this level.

Field trips as academic tourism programs have primarily emerged in many schools or institutions. It can be said that, school or institutions have consider the needs and expectancies of tourism sectors. It clears that there is diversity in opinions and approaches on tourism education systems. This diversity leads to a wide range of lesson curricula available at tourism education at schools or institutions. In addition, the curricular variations may be observed among tourism education (Mayoka and Akama 2007; Amoah and Baum, 1997; Barrows and Bosselman, 1999; Dale and Robinson, 2001; Okumuş and Yağc1, 2006; Zagonari, 2009).

Field trips can be considered as difficult activities to be organized and supervised. But the benefit of field trips activities can provide learning opportunities that cannot be experienced in the classroom. The students can have are a good way to communicate difficult information. Through educational field trips most of the concepts and phenomena may be easily clarified, understood and assimilated. And with these activities, a great deal of energy and time of both the teachers and students can be saved. The activity of educational field trips which are commonly conducted for the students at higher level are one of the major source of providing knowledge to the students by giving opportunity for self-experiences and observations and self-long-lasting learning.

April sanders clear that going on a field trip is a wonderful way to extend a learning experience in such a way that the students not only understand the concept, but also understand how it connects to their world. Eric Powell describes that field trips are vital for students to have a chance to view and explore historical places and different social institutions. They provide an opportunity for the students to visiting a new place, meeting new people and seeing and understanding the things. Educational field trips are very important because they are a way to bring the students closer together, they are very helpful for physical fitness of students, and they are also a source of entertainment. Educational field trips are very helpful to provide a future professional and vocational direction. They open the eyes of students, not only with information but with ideas also.

\section{Literature Review}

\subsection{Field Trip}

Field trip is an activity or a trip that is carried out by a group of people for recreation or vacation that related to education. The main aim of field trip in an educational institution is not only for recreation and vacation but also to support tourism and gain additional knowledge through direct experiences that cannot be gotten in classroom. Therefore, field trip is a tour that has an added value to education. Similarly, Sampath et al (2006) says that the students have concrete learning experiences in a real situation which has been undertaken with a specific purpose in the field trips.

In university level, field trip is an organized visit taken by the students and teachers (lecturers) to get further educational purposes of the regular classroom activities. The purpose is for educational observation, nonexperimental research or providing students with real experiences. In other words, it provides students the first-hand experiences that cannot be obtained in the classroom. Aggarwal (2008) describes that the educational field trips aim to enrich, vitalize and complement content areas of the curriculum and give also direct experience outside the classroom. Similarly, Randy Wilhelm says that "Field trip is a substantive way to expand student's horizons and allow them to learn experientially". Field trips give them a chance to get out of the classroom and new experience which is necessary for their level. According to Youth learn initiative "field trips are a great way to bring excitement and adventure to learning." It allows students to have a real world experiences. 
The advantages of field trips are: 1) students gain real-world experiences, 2) students' quality of education increased, 3) students' positive attitudes to science and motivation towards the subjects improved, 4) the socialization between students improved, 5) relationship between teachers and students developed, 6) teachers able to utilize other learning strategies such as cooperative learning.

The types of educational field trips conducted by institution according to Sampath et al (2006) are: Local Trips, Community Trips, Tour or Journey, Imaginary Tours, Inter-school Visits and Individual Trips. Field trips are most often held in 3 steps, they are: 1) preparation, 2) activities and 3) follow-up activity. Both teacher and students need to do the preparation before the field trip. The teachers learn the destination, the subject and the purpose before the trip. As Myers and Jones (2015) describe that educational field trips should be designed well based on the educational objectives. It should be planned as a cooperative activity involving full students' participation under the teacher's supervision. The students and teachers role should be clear. The second step is activity. The activities of field trips often include: lectures, tours, worksheets, videos and demonstrations. The final step is follow-up activities. They are discussions, debriefing and culminating activity that occur in the classroom once the field trip has been completed.

\subsection{Edu-Tourism}

Edu-tourism or Educational Tourism can be defined as tourism activity carried out by those who take a short vacation and those who travel for education and learning as a primary part of the trip. This may include the general educational tourism and adult study tours, international/domestic university and school students' travel, such as: language schools, school excursions, and exchange programmes. According to Ritchie et al (2003), educational tourism can be independently or formally organised and also can be undertaken in a variety of natural or human made settings.

Bodger (1998) defined education tourism or edu-tourism as "a program in which participants travel to "location as a group with the main goal to be involved in direct learning experiences related to the location". Edu-tourism consists of ecotourism, heritage tourism, rural/farm tourism, or student exchanges between educational institutions. Those activities were adjusted to the institution learning method, subjects, and curriculum.. To manage edu-tourism destination, the management need to understand the scientific contribution to institution who visited those places.

It emphasized that edu-tourism tourists are educational practitioners such as students, teachers, academic staffs and researchers. Guo (2000,pp.4-6) noted that Educational-Tourism is "a kind of special short-term tourism whose purpose is to learn and gain knowledge and whose main participants are students. Therefore, the activities of education tours were various, such as get to know a school, attend a seminar, attend an academic or research project (Yuan, 2003, pp.10). Wang and Li (2013) discovered that "field trip destinations were always set in reputed schools/ institutes/ universities or some historical sites and famous scholars' residence. It is expected that each participants obtain skills, enrich knowledge in the trips and upgrade tourist's products for the local tourism industry."

In broader context, edu-tourism is not just travel arrangement made for scholars, but also for people in the society. People who would like to travel by the cultural motivation usually searched for learning element and education. Before this idea appeared, Bourdieu (1984) argued that "to understand and appreciate cultural products, people must have a cultural competency or cultural capital that allows them to recognize and interpret these products". Thus, Ritchie (2009) stated that this ability could be gained through "growth, education and other forms of socialization". So, the growing number of activities and demand of edu-tourism has encouraged the enhancement of tourism occupational competency. This competency would be incorporated in tourism education system.

\subsection{English Speaking Ability in the Tourism Industry}

Tourism is a business activity which involves people travelling to destinations outside their normal place of residence for a short period of time (Chilembwe, 2010). People travel to learn new cultures, languages and places, achieve their personal development, and elevate their social status. The increasing of travel need affect to interesting, communicative and informative tour guide demand.

As a result, communication skill become one of important requirement in the tourism industry. In such context, English has been increasingly important tool of communication by native and non-native English speakers all over the world since it has been recognized as the global language. It plays an important role in the tourism industry as a tool for tourism workers to communicate with the tourists (Prachanant, 2012). Therefore it is quite important to improve students English speaking ability especially at university level. 


\section{Method}

This is a qualitative study which is carried out by survey and observation. The population of this study is the English Department students of Potensi utama University. The sample is taken from the fifth semester students (50 students) and some lectures (10 lecturers) which involved in the field trip programmes. The field trip was held in the ecotourism of Bukit Lawang, which was located at Bahorok sub-district, Langkat Regency, North Sumatera, Indonesia. The instrument of this study used questionnaire and speaking test items. The data had been analysed by using simple percentage method. The result of this study is hoped that educational field trips are helpful to cope up with advance learning to develop students' interest especially speaking ability.

\section{Results and Discussion}

The collected data was converted into tables. Findings and conclusions were drawn in the light of these tables by the researchers.

Table 1. The Pre-Test Analysis of Students' Speaking Ability

\begin{tabular}{|l|c|c|c|}
\hline \multicolumn{1}{|c|}{ Category } & Value Range & Frequency & Percentage \\
\hline Very Good & $80-100$ & 1 & $2 \%$ \\
\hline Good & $70-79$ & 4 & $8 \%$ \\
\hline Sufficient & $60-69$ & 15 & $30 \%$ \\
\hline Poor & $50-59$ & 25 & $50 \%$ \\
\hline Very Poor & $0-49$ & 5 & $10 \%$ \\
\hline \multicolumn{2}{|r|}{} & 50 & $100 \%$ \\
\hline
\end{tabular}

The pre-test result showed that there was 1 student in very good category (2\%), there were 4 students $(8 \%)$ who had the ability to speak English in good category, 15 students (30\%) in the sufficient category, 25 students $(50 \%)$ in the poor category, and 5 students $(10 \%)$ in the very poor category.

Table 2. The Post-Test Analysis of Students' Speaking Ability

\begin{tabular}{|l|c|c|c|}
\hline \multicolumn{1}{|c|}{ Category } & Value Range & Frequency & Percentage \\
\hline Very Good & $80-100$ & 8 & $16 \%$ \\
\hline Good & $70-79$ & 11 & $22 \%$ \\
\hline Sufficient & $60-69$ & 26 & $52 \%$ \\
\hline Poor & $50-59$ & 4 & $8 \%$ \\
\hline Very Poor & $0-49$ & 1 & $2 \%$ \\
\hline \multicolumn{2}{|r|}{} & 50 & $100 \%$ \\
\hline
\end{tabular}

The post-test result showed that there were significant increases on the students' speaking ability that 1 student $(2 \%)$ in pre-test increased become 8 students $(16 \%)$ in very good category, 4 students $(8 \%)$ who had the ability to speak English in good category in pre-test increased become 11 students (22\%), 15 students $(30 \%)$ in the sufficient category in pre-test became 26 students $(52 \%)$ in post-test. Meanwhile, there were some decreases. There were 25 students (50\%) in the poor category in re-test decreased become 4 students $(8 \%)$ in post-test, and 5 students $(10 \%)$ in the very poor category i pre-test became 1 student (2\%) in posttest.

Table 3. The questionnaire for Teacher

The Usefulness of Field Trip in Effective Learning

\begin{tabular}{|c|c|c|c|}
\hline No & Usefulness of Field Trip & Teacher & Percentage \\
\hline
\end{tabular}




\begin{tabular}{|l|l|c|c|c|}
\hline & & Yes & No & \\
\hline 1 & Provide practical approach to curriculum & 9 & 1 & $90 \%$ \\
\hline 2 & Provide students' self experience \& observation & 8 & 2 & $80 \%$ \\
\hline 3 & Guide to face future obstacles and challenges & 7 & 3 & $70 \%$ \\
\hline 4 & Promote interaction among students and teachers & 6 & 4 & $60 \%$ \\
\hline 5 & Provide students' psychological need satisfaction & 7 & 3 & $70 \%$ \\
\hline 6 & Develop learning among students become more interesting & 8 & 2 & $80 \%$ \\
\hline 7 & Help to realize professional skills awareness & 8 & 2 & $80 \%$ \\
\hline 8 & Overcome the teaching / learning difficulties & 8 & 2 & $80 \%$ \\
\hline 9 & Provide students an opportunity to show personalities & 6 & 4 & $60 \%$ \\
\hline
\end{tabular}

The result showed that most of the teachers think that field trips provide practical approach to curriculum, provide self-experience and observation, develop more interesting learning difficulties and provide students an opportunity to show personality.

Table 4. The questionnaires for Teacher

Field Trip Promotes Students' Qualities

\begin{tabular}{|l|l|c|c|c|}
\hline No & \multicolumn{1}{|c|}{ Promote Students' qualities } & \multicolumn{2}{|c|}{ Teacher } & \multirow{2}{*}{$\begin{array}{c}\text { Percentage } \\
\text { (\%) }\end{array}$} \\
\cline { 3 - 5 } & & Yes & No & $80 \%$ \\
\hline 1 & Developing the balanced personality & 8 & 2 & $90 \%$ \\
\hline 2 & Promoting students' cooperation and unity & 9 & 1 & $100 \%$ \\
\hline 3 & Developing leadership qualities & 10 & 0 & $90 \%$ \\
\hline 4 & Promoting sense of discipline & 9 & 1 & $80 \%$ \\
\hline 5 & Increasing self confidence & 8 & 2 & $90 \%$ \\
\hline 6 & Helpful in social training & 9 & 1 & 8 \\
\hline
\end{tabular}

The result showed that most teachers think that field trip is helpful to develop leadership qualities, promote students' cooperation and unity, promote sense of discipline and helpful students in social training.

Table 5. The questionnaire for Teacher

The Nature of Field Trips

\begin{tabular}{|l|l|c|c|c|}
\hline \multirow{2}{*}{ No } & \multicolumn{1}{|c|}{ The Essentials of Field Trips. } & \multicolumn{2}{c|}{ Teacher } & Percentage \\
\cline { 3 - 4 } & & Yes & No & $(\%)$ \\
\hline 1 & Give students opportunity in organizing trips & 8 & 2 & $80 \%$ \\
\hline 2 & Enable students in adopting learning techniques & 7 & 3 & $70 \%$ \\
\hline 3 & Enable students make a field trip report & 9 & 1 & $90 \%$ \\
\hline
\end{tabular}

The results showed that most teachers think that they had given students opportunity to organize field trips and enable them to make a report after the trip.

Table 6. The questionnaire for Students

The Usefulness of Field Trip in Effective Learning

SALTeL Vol. 3, No. 2, 2020: $44-50$ 


\begin{tabular}{|l|l|c|c|c|}
\hline \multirow{2}{*}{ No } & & \multicolumn{2}{c|}{ Teacher } & Percentage \\
& The Usefulness of Field Trip in effective learning & Yes & No & $(\%)$ \\
\hline 1 & Provide practical approach to curriculum & 8 & 2 & $80 \%$ \\
\hline 2 & Provide students' self experience \& observation & 9 & 1 & $90 \%$ \\
\hline 3 & Guide to face future obstacles and challenges & 7 & 3 & $70 \%$ \\
\hline 4 & Promote interaction among students and teachers & 6 & 4 & $60 \%$ \\
\hline 5 & Provide students' psychological need satisfaction & 7 & 3 & $70 \%$ \\
\hline 6 & Develop learning among students become more interesting & 8 & 2 & $80 \%$ \\
\hline 7 & Help to realize professional skills awareness & 8 & 2 & $80 \%$ \\
\hline 8 & Overcome the teaching/learning difficulties & 8 & 2 & $80 \%$ \\
\hline 9 & Provide students an opportunity to show personalities & 6 & 4 & $60 \%$ \\
\hline
\end{tabular}

The result showed that most of students think that field trips provided self-experience and observation to increase their knowledge.

Table 7. The questionnaires for Students

Field Trip Promotes students' Qualities

\begin{tabular}{|l|l|c|c|c|}
\hline \multirow{2}{*}{ No } & \multicolumn{1}{|c|}{ Promotion of qualities among students } & \multicolumn{2}{|c|}{ Teacher } & \multirow{2}{*}{$\begin{array}{c}\text { Percentage } \\
\text { (\%) }\end{array}$} \\
\cline { 3 - 4 } & & Yes & No & $80 \%$ \\
\hline 2 & Developing the balanced personality & 8 & 2 & $80 \%$ \\
\hline 3 & Promoting students' cooperation and unity & 9 & 1 & $90 \%$ \\
\hline 4 & Developing leadership qualities & 10 & 0 & $100 \%$ \\
\hline 5 & Increasing self confidence & 9 & 1 & $90 \%$ \\
\hline 6 & Helpful in social training & 8 & 2 & $80 \%$ \\
\hline
\end{tabular}

The result showed that most of students think that field trips at higher level promotes students' qualities in leadership, cooperation, social training among them.

Table 8. The questionnaire for Students

The Nature of Field Trips

\begin{tabular}{|l|l|c|c|c|}
\hline \multirow{2}{*}{ No } & \multicolumn{1}{|c|}{ The Nature of Field Trips. } & \multicolumn{2}{|c|}{ Teacher } & \multirow{2}{*}{$\begin{array}{c}\text { Percentage } \\
\text { ny }\end{array}$} \\
\cline { 3 - 4 } & & Yes & No & \\
\hline 1 & Give students opportunity in organizing trips & 9 & 1 & $90 \%$ \\
\hline 2 & Enable students in adopting learning techniques & 7 & 3 & $70 \%$ \\
\hline 3 & Enable students make a field trip report & 8 & 2 & $80 \%$ \\
\hline
\end{tabular}

The results showed that most of students think that they had a chance to learn more from field trips by organizing and reporting it after the trip.

\section{Conclusion}

Based on the results, it can be concluded that; first, the implementation of field trip as edu-tourism is significantly improve the students speaking ability at university level. Second, most of the responses showed 
that there was lot of importance of field trips at higher level. It is not only helpful in effective learning but also promote the students' qualities. Short number of responses shows that the trips enable the students to organize and report it.

\section{References}

Aggarwal, J.C. (2008). "Principles \& methods \& techniques of teaching”, Vikas publishing house pvt Ltd.

Bodger, D. (1998). Leisure, learning, and travel. Journal of Physical Education Recreation Dance, 69 (4), 2831

Guo Yixin. (2000).Vocation Economy. Guangzhou: Guangzhou Economics Press,(Chapter 1)

Myers, B., and Jones L. (2015) "Effective Use of Field Trips in Educational Programming: A three Stage Approach", Agricultural Education and Communication Department.

Sampath, K. Panneerselvam. A, \& Santhanam.S (2006). "Introduction to educational technology", Sterling publishers Pvt Ltd.

Ritchie, Brent W., Carr, N. \& Cooper, C. (2003) "Aspects of Tourism: Managing Educational Tourism", Cromwell Press.

Wang, Bin and Li, Shen. Bin Wang. (2008). Education Tourism Market in China An Explorative Study in Dalian. Vol. 3, No. 5 International Journal of Business and Management. 